\title{
Evaluation Seed-born Fungi of Rice [Oryza sativa L.] and that Effect on Seed Quality
}

\section{Salar Monajjem ${ }^{1 *}$, Ebrahim Zainali ${ }^{2}$, Farshid Ghaderi-Far ${ }^{2}$, Elias Soltani ${ }^{3}$, Maryam Hosseini Chaleshtari ${ }^{4}$ and Maryam Khoshkdaman ${ }^{5}$}

${ }^{1}$ Ph.D Student of Seed Science and Technology

${ }^{2}$ Assistant Prof., Dept. of Agronomy, Gorgan University of Agricultural Sciences and Natural Resources

${ }^{3}$ Assistant Prof., Dept. of Agronomy, University of Tehran

${ }^{4}$ Assistant Prof., Rice Research Institute of Iran

${ }^{5}$ Scholar of Rice Research Institute of Iran

\begin{abstract}
Poor seedling establishment in rice is one of the problems in Guilan province as the second most important rice-growing locations in Iran. The aim of this study was to evaluate the contamination occurrence of rice seed in five locations of Guilan province to seed-borne fungi and their effects on germination characteristics. Five seed sample of Hashemi variety obtained from leading farmers from each location, and their germination characteristics and the rate of contamination to Fusarium moniliforme, Bipolaris oryzae, Aspergillus niger, A. flavus, Penicillium sp., Alternaria padwickii was evaluated using the PDA and standard blotter methods. The assessment results showed that among the seed-borne fungi, two species $A$. niger and $A$. flavus exhibited the highest severity in both methods. Samples from Rasht and Zeybaknar locations showed the most contamination to $A$. flavus and $A$. niger. A positive and significant linear relationship was observed between daily precipitation and relative humidity with severity of $A$. flavus and $A$. niger fungus. A. niger, A. padwickii, daily precipitation and average minimum temperature had the most influence on germination characteristics. Among the studied factors, A. niger had high negative impact compared to other factors on all rice seed germination characteristics. Among the study locations, quality of seeds in RostamAbad in terms of germination percentage, germination rate, germination uniformity and electrical conductivity had the best state. The results of this study showed that the low precipitation and low daily average humidity along with higher number of sunshine hours in the Rostam-Abad caused reduction in activity and abundance of fungi, led to improve the quality of produced seed.
\end{abstract}

Keywords: Seed-borne fungi; Rice; Seed quality; Climatic conditions

\section{Introduction}

Seed is the primary basis of crop production and is the most important available input factor for smallholder farmers [1]. In most parts of the world, smallholder farmers use their produced seed for next year planting, consequently, they attempt to stock their own produced seed for several months to several years. These seeds are often of poor quality, impure and contaminated with pathogens [2]. Seed contamination of pathogens during storage could reduce seed vigor, germination, and cause negative effect on appearance and chemical composition of seeds in addition to accelerate seed deterioration, it can also inhibit germination, transmission of the pathogen from seed to seedling or main plant leading to reduction in crop yield and threatened food security [3].

Food security of the world depends on sufficient production of small seed cereals as the cheapest source that provided about 70 of absorbable energy [4]. Based on seed production, rice is the second small seed cereals, with area under cultivation about 154 million hectares, with a global production of 720 million tons of paddy [5].

Rice is very important in Iran and it provides substantial part of the diet, especially in the three Northern provinces; Guilan, Mazandaranand and Golestan. Total rice cultivation area in the country is approximately 600 thousand hectares. Guilan province with 230 thousand hectares of rice fields with an average of 0.8 hectares of land owned by each farmer has the second place in rice production. In this province, from total rice seeds which are used by farmers only about 5 percent are considered as certified seed and the other 95 percent is produced by farmers and keep maintained in On-farm storages until sowing [6].

Different research studies have stated that in poor storage conditions, pathogens are the most important factors which not only cause the seed aging and deterioration during storage, but also seed and seedling rotting or abnormal production of seedlings in nursery $[7,8]$. Several reports indicated that the majority of these pathogens that lead to the production of abnormal seedlings are seed-borne fungi [9]. The rate of damage of these fungi depends on their genus and species, rate of density, fungi invaded, environmental conditions, cultivar susceptibility and interaction of these factors on cultural practice [10].

More than 100 species of fungi have been identified on rice seeds so far. However, their severity depends on the time of sampling, location and varieties are different [11-13]. Through an assessment of rice seed contamination to different seed-born fungi, 8 genera including 12 species of fungi were identified which among them Bipolaris oryzae with $59 \%$ and Alternaria padwickii with 53\% had the highest severity [13]. Ahmed et al. [9] in their study on rice seed contamination identified 9 species of seed-born fungi including; Fusarium oxysporum, F. moniliforme, Bipolaris oryzae, Alternaria padwickii, Curvularia lunata, Aspergillus flavus, A. niger, Penicillium sp. and Nigrospora oryzae. They

${ }^{*}$ Corresponding author: Salar Monajjem, Phd student in seed technology Agronomy Group, Gorgan University of Agriculture Science \& Nature Resource, Iran, Tel: +989364146800; E-mail: gromonajem@gmail.com

Received: July 21, 2014; Accepted November 11, 2014; Published November 13,2014

Citation: Monajjem S, Zainali E, Ghaderi-Far F, Soltani E, Chaleshtari MH, et al (2014) Evaluation Seed-born Fungi of Rice [Oryza sativa L.] and that Effect on Seed Quality. J Plant Pathol Microb 5: 239. doi:10.4172/2157-7471.1000239

Copyright: @ 2014 Monajjem S, et al. This is an open-access article distributed under the terms of the Creative Commons Attribution License, which permits unrestricted use, distribution, and reproduction in any medium, provided the original author and source are credited. 
stated that the most common fungal contamination in examined seed samples was related to Bipolaris oryzae and Alternaria padwicki. Uma and Wesely [14] by studying on 5 seed varieties after ending storage period in India, identified seeds contamination to Aspergillus flavus, A. niger, Penicillium citrinum, Alternaria padwickii and Rhizopus oryzae in which, A. flavus with $18 \%$ and $A$. niger with $17.6 \%$ had the highest severity . Van Du et al. [15] studied the seed-borne fungi which were identified from samples of rice varieties in different locations in Vietnam and reported that there was a significant difference for fungus severity among the cultivars, but not for different locations of seed production. In their study, contamination to seed-born fungi in improved varieties was more than local varieties causing reduction in germination and seedling height percentage in these varieties. Among seed-borne fungi, the most severity in different varieties was related to A. padwickii. A. padwickii has led to reduction of germination stronger than others fungus. Karami et al. [16] studied the effect of Fusarium spp. and brown spot [Bipolaris oryzae] on seed germination of high yield rice varieties and reported that germination percentage and seedling growth on studied cultivars has declined due to fungal contamination.

The quality of used seeds in the establishment of normal seedlings is important. The contamination of seeds to seed-borne fungi during storage by reducing seed quality affects on seed germination and establishment of seedling. By considering the self-consumption of rice seed in the rice seed production system in Guilan, and inappropriate condition during on-farm storage, it seems that performing targeted basic-applied research in this field is necessary. Hence, the present study was carried out to evaluate the contamination of rice seed for Hashemi variety, which is commonly used by farmers in different locations of Guilan province, to seed-borne fungi and its effect on germination characteristics.

\section{Methods and Materials}

Guilan province located between $38^{\circ}-27^{\prime}-7^{\prime \prime}$ to $36^{\circ}-36^{\circ} 3^{\prime \prime}$ north latitude and $50^{\circ}-26^{\prime}-42^{\prime \prime}$ to $48^{\circ}-34^{\prime}-25^{\prime \prime}$ east of the Greenwich meridian, between the heights of the Alborz Mountains and humidity resource of the Caspian Sea. However, among various locations of rice production in Guilan, in terms of the rate of precipitation, temperature, relative humidity and sunshine hours are different [17]. Hence, this evaluation was carried out in the spring of 2013 by using of seed samples collected from 5 different locations of Guilan including Amlash, Zeybaknar, Talesh, Rasht and Rostam-Abad. Meteorological data in the studied locations of Guilan province during six months of plant growth period [2012/03/01 to 2012/09/01] and the seed development is presented in Table 1. From each location after the end of seed harvesting, five seed samples of Hashmi which is the local dominant variety in Guilan province randomly received from the leading farmers. All samples stored in similar condition in cold storage at $5^{\circ} \mathrm{C}$ for 6 months.

Seeds germination characteristics were evaluated by using standard germination test in a completely randomized design with four replications in Petri-dishes with $9 \mathrm{~cm}$ diameter. For this reason, the first seed surface dis contaminated for the purpose of determining the presence of internal fungi in seed with sodium hypochlorite [5\%] for 1 min and then washed 3 to 5 times with distilled water [18]. Then, after laying one Whatman filter paper at the bottom of each Petri-dish, 25 seeds of each sample were placed on filter paper and after adding 5 $\mathrm{ml}$ of distilled water, to retain moisture Petri dish lid were placed on them. Then Petri-dishes were transferred to growth chamber at $25^{\circ} \mathrm{C}$, with normal light and relative humidity of $70 \pm 5$ percent [19]. During the experiment [ 7 days] once in every 8 hours germination seeds were counted, based on root let criteria in size of $2 \mathrm{~mm}$ or more [20]. Using of obtained data, germination characteristics including germination percentage, germination rate, germination uniformity, D10, D50 and D95 [in order of time that it takes to cumulative germination percentage reach its maximum 10,50 and 95] were calculated by Germin program [21]. In order to perform the electrical conductivity test [electrical conductivity which represented the amount of material was leakage from seed], the seeds washed with deionized water to remove contaminated surface of seeds, then $5 \mathrm{~g}$ of seeds immerse in 50 $\mathrm{ml}$ of distilled water at $25^{\circ} \mathrm{C}$ and after 24 hours electrical conductivity of solution measured by conductivity meter device model LF 90 SERNA31245385 [22].

In vitro potato dextrose agar method [PDA] and standard blotter method were employed to identify the seed-borne fungi of Fusariummoniliforme, Bipolarisoryzae, Aspergillusniger, Aspergillusflavus, Penicillium sp., Alternariapadwickii and to determine their contamination percentage. In both methods, seeds were soaked for 5 minute at sodium hypochlorite [1\%] solution and immediately washed with distilled water 3 to 5 times in order to prevent fungal pathogens infection [23]. In PDA method for each sample was performed with four replications, in each Petri dish poured some prepared of PDA then with sterile forceps under the hood 10 seeds were placed on the in PDA [23] (Figure 1). After six days Petri dishes were placed at a temperature of $22^{\circ} \mathrm{C}$ incubator, seed born fungi were identified and contamination rate of seeds to these factors were evaluated [24]. The standard Blotter method for each sample was carried out with 400 seeds, in each Petri dishes, three layers of Whatmann filter papers soaked with distilled water and were placed with 25 seeds. Petri dishes [16 Petri dishes for per sample] for incubating placed in temperature of $22^{\circ} \mathrm{C}$ then 6 days in alternating cycles of 12 hours near

\begin{tabular}{|c|c|c|c|c|c|c|c|c|c|c|c|}
\hline & \multirow{2}{*}{$\begin{array}{l}\text { Seed development } \\
\text { period [heeding to } \\
\text { harvest maturity] }\end{array}$} & \multicolumn{2}{|c|}{$\begin{array}{c}\text { Maximum temperature } \\
\text { average }\left[{ }^{\circ} \mathrm{C}\right]\end{array}$} & \multicolumn{2}{|c|}{$\begin{array}{c}\text { Minimum temperature } \\
\text { average }\left[{ }^{\circ} \mathrm{C}\right]\end{array}$} & \multicolumn{2}{|c|}{ Daily sunny hours } & \multicolumn{2}{|c|}{ Daily precipitation [mm] } & \multicolumn{2}{|c|}{ Daily relative humidity } \\
\hline & & $\begin{array}{c}\text { Seed } \\
\text { develop. } \\
\text { period }\end{array}$ & $\begin{array}{l}2012 / 03 / 01 \text { to } \\
2012 / 09 / 01\end{array}$ & $\begin{array}{c}\text { SEED } \\
\text { develop.period }\end{array}$ & \begin{tabular}{|c|}
$2012 / 03 / 01$ to \\
$2012 / 09 / 01$
\end{tabular} & \begin{tabular}{|c|} 
Seed \\
develop. \\
period
\end{tabular} & $\begin{array}{c}2012 / 03 / 01 \\
\text { to } \\
2012 / 09 / 01\end{array}$ & $\begin{array}{l}\text { Seed } \\
\text { develop. } \\
\text { period }\end{array}$ & $\begin{array}{c}2012 / 03 / 01 \\
\text { to } \\
2012 / 09 / 01\end{array}$ & $\begin{array}{c}\text { Seed } \\
\text { develop. } \\
\text { period }\end{array}$ & $\begin{array}{l}2012 / 03 / 01 \text { to } \\
2012 / 09 / 01\end{array}$ \\
\hline Amlash & $\begin{array}{l}2012 / 07 / 05 \text { to } \\
2012 / 08 / 15\end{array}$ & 31.15 & 27.02 & 21.03 & 16.85 & 7.75 & 6.26 & 1.02 & 3.04 & 72.42 & 73.90 \\
\hline Zeybakenar & $\begin{array}{l}2012 / 06 / 30 \text { to } \\
2012 / 08 / 10\end{array}$ & 29.88 & 26.34 & 21.75 & 18.48 & 7.95 & 6.87 & 3.70 & 2.05 & 73.45 & 74.23 \\
\hline Rasht & $\begin{array}{l}2012 / 06 / 30 \text { to } \\
2012 / 08 / 10\end{array}$ & 30.34 & 27.29 & 21.43 & 17.99 & 6.92 & 6.41 & 3.10 & 2.89 & 81.22 & 80.91 \\
\hline Talesh & $\begin{array}{l}2012 / 07 / 05 \text { to } \\
2012 / 08 / 15\end{array}$ & 30.54 & 25.89 & 22.17 & 17.83 & 7.36 & 6.01 & 1.20 & 2.72 & 69.01 & 74 \\
\hline Rostam-Abad & $\begin{array}{l}2012 / 08 / 05 \text { to } \\
2012 / 09 / 10\end{array}$ & 30.05 & 28.79 & 22 & 19.43 & 8.30 & 7.24 & 0.10 & 0.50 & 65.80 & 63.99 \\
\hline
\end{tabular}

Table 1: Meteorological information for different locations of seed production of Guilan province during seed development period and six months of year in 2012. 
Citation: Monajjem S, Zainali E, Ghaderi-Far F, Soltani E, Chaleshtari MH, et al. (2014) Evaluation Seed-born Fungi of Rice [Oryza sativa L.] and that Effect on Seed Quality. J Plant Pathol Microb 5: 239. doi:10.4172/2157-7471.1000239

Page 3 of 7

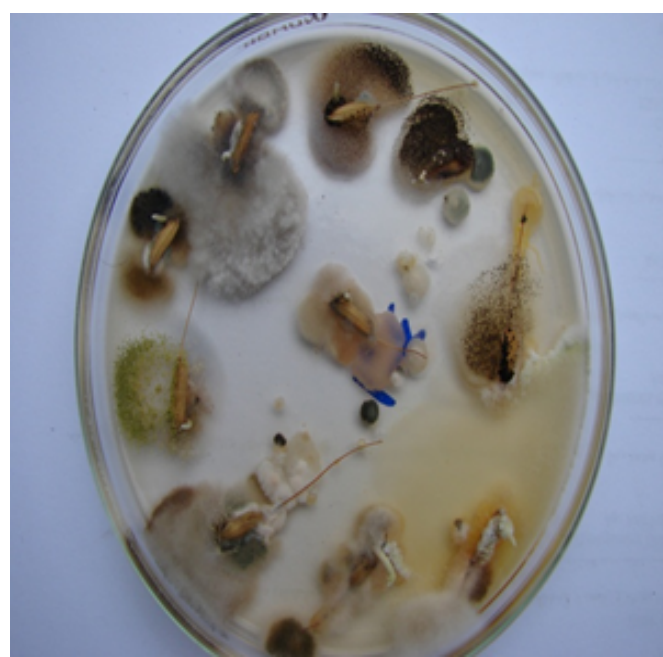

Figure 1: Potato Dextrose Agar method [PDA].

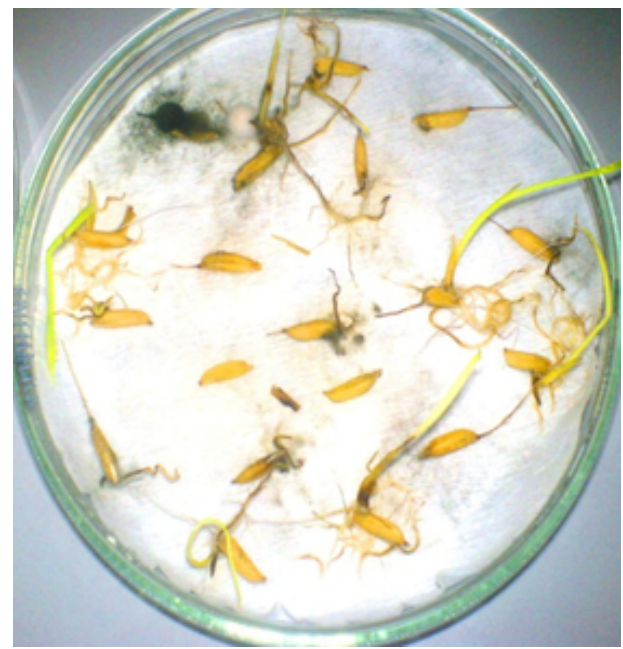

Figure 2: Standard blotter method.

ultraviolet light and 12 hours in darkness. At the seventh day grown fungi on seeds germination were identified by using of a stereo microscope and number of infected seeds in each seed sample marked and calculation was performed as contamination percentage [24] (Figure 2).

Data analysis conducted by stepwise regression, ANOVA and multiple comparison using LSD test was performed by using of SAS [25] software.

\section{Results and Discussion}

The results showed differences between evaluated locations from contaminated rate point of view to seed-borne fungi and also different severity of contaminated seeds to various fungi included Fusarium moniliforme, Bipolaris oryzae, Aspergillus niger, Aspergillus flavus, Penicillium sp., Alternaria padwickii (Table 2). In examined seed samples, among rice seeds borne fungi, Aspergillus niger and Aspergillus flavus in both evaluated methods [Standard blotter method and PDA method] had the most severity than the other fungi species (Table 3 ), these data confirms the results reported by Uma and Wesely [14] which they stated that $A$. flavus and $A$. niger fungi as the most important storage fungi could be active in seed moisture content below 20 percent. Trung et al. [26] by examination on the 25 seed samples of rice in Vietnam mentioned that genus of fungus Aspergillus, Fusarium and Penicillium were the most common fungi. Reddy et al. [27] in their study on stored rice for more than a year from 18 different ecosystems in India were stated that Aspergillus is the most important fungal contamination on rice seeds.

Among the five different evaluated locations, samples from Rasht and Zeybakenar had the most contamination to rice seed-borne fungi, and the most severity fungi were A. flavus and A. niger (Table 3). Reddy et al. [27] stated that weather conditions before harvesting could be the most important factors that led to invasion of fungal species. MosaNejad et al. [28] reported that the rate of precipitation, daily minimum humidity, daily maximum temperature and sunshine hours could be the most important factors affecting the distribution of rice blast in Guilan province so that suitable climatic conditions could considerably help to spore population of blast fungi and occurrence of blast disease in farm during seven to ten days after occurrence of suitable conditions. Aghili et al. [29] by study on the rice fungal contamination in Mazandaran province stated that increasing average humidity in the west of Mazandaran could be the reason for the severity of fungal contamination of the seeds. Also, the results showed that under high humidity conditions, fungi of genus Aspergillus had the most severity which corresponded with the obtained results in this research.

In the present study with regard to fungal contamination rate as a dependent variable, and climatic factors including; daily relative humidity, number of daily sunny hours, daily precipitation and minimum average temperature were entered to the regression model, respectively. Stepwise regression analysis showed that the daily humidity, the amount of daily sunshine hours, daily precipitation and minimum average temperature are the most important climatic factors that affected the distribution of different types of the evaluated seedborne fungi except Fusarium moniliforme and Bipolaris oryzae (Table 4). The stepwise regression analysis on climatic factors affecting severity of fungi $A$. flavus and $A$. niger determined that precipitation and daily humidity could be the most influential factors in distribution of rice

\begin{tabular}{|c|c|c|c|c|c|c|c|c|c|}
\hline & DF & $\begin{array}{l}\text { Fusarium } \\
\text { moniliforme }\end{array}$ & $\begin{array}{c}\text { Pyryicularia } \\
\text { oryzae }\end{array}$ & $\begin{array}{c}\text { Bipolaris } \\
\text { oryzae }\end{array}$ & Aspergillus niger & Aspergillus flavus & Penicillium sp. & $\begin{array}{l}\text { Alternaria } \\
\text { padwickii }\end{array}$ & $\%$ total infection \\
\hline Methode & 1 & $33.40^{*}$ & $143.41^{\star \star}$ & $138.44^{* *}$ & $2892.18^{\star *}$ & 442.50ns & $367.90^{* *}$ & $6.59 \mathrm{~ns}$ & $2304.59^{\star *}$ \\
\hline Location & 4 & $142.33^{* *}$ & $42.80^{* *}$ & $176.32^{* *}$ & $11491.03^{* *}$ & $868.48^{* *}$ & $221.06^{\star \star}$ & $156.27^{\star \star}$ & $10789.87^{\star *}$ \\
\hline Location $\times$ Methode & 4 & $46.96^{* *}$ & $38.09^{* *}$ & $16.28^{* *}$ & $244.76^{\star *}$ & $139.65^{\star *}$ & $188.09^{* *}$ & $30.45^{\star *}$ & $884.97^{* *}$ \\
\hline $\begin{array}{l}\text { Rep[Methode* } \\
\text { Location] }\end{array}$ & 30 & 0.94 & 0.41 & 3.01 & 62.44 & 18.76 & 2.38 & 0.73 & 123.74 \\
\hline Error & 160 & 31.23 & 6.65 & 33.18 & 626.53 & 275.62 & 19.42 & 10.14 & 435.55 \\
\hline Coefficient Variance & & 8.67 & 6.83 & 6.61 & 7.85 & 7.76 & 6.66 & 6.95 & 3.37 \\
\hline
\end{tabular}

ns: non-significant, ${ }^{*}$ and ${ }^{* *}$ : Significant at $5 \%$ and $1 \%$ probability levels, respectively.

Table 2: Analysis of variance for seed-born fungi in rice seed samples in different locations of seed production of Guilan province. 
Citation: Monajjem S, Zainali E, Ghaderi-Far F, Soltani E, Chaleshtari MH, et al. (2014) Evaluation Seed-born Fungi of Rice [Oryza sativa L.] and that Effect on Seed Quality. J Plant Pathol Microb 5: 239. doi:10.4172/2157-7471.1000239

Page 4 of 7

\begin{tabular}{|c|c|c|c|c|c|c|c|c|c|c|}
\hline $\begin{array}{l}\text { Seed } \\
\text { production } \\
\text { location }\end{array}$ & Method & $\begin{array}{l}\text { Number of } \\
\text { Sample }\end{array}$ & Fusariummoniliforme & $\begin{array}{c}\text { Pyryicularia } \\
\text { oryzae }\end{array}$ & Bipolarisoryzae & Aspergillusniger & Aspergillusflavus & $\begin{array}{c}\text { Penicillium } \\
\text { sp. }\end{array}$ & Alternariapadwickii & $\begin{array}{l}\text { \%total } \\
\text { infection }\end{array}$ \\
\hline \multirow{2}{*}{ Amlash } & PDA & 5 & $0 \mathrm{~g}^{*}$ & $2.51 \mathrm{~b}$ & $6.2 \mathrm{~b}$ & $5.14 f$ & 16.33ab & $2.06 \mathrm{e}$ & $0 \mathrm{~g}$ & $19.40 \mathrm{~d}$ \\
\hline & Blotter & 5 & $0.25 f$ & $0 \mathrm{e}$ & $4.68 \mathrm{bc}$ & $3.32 f$ & $11.94 \mathrm{dc}$ & $1.31 \mathrm{ef}$ & $0.90 \mathrm{e}$ & $17.79 d$ \\
\hline \multirow{2}{*}{ Zeybakenar } & PDA & 5 & $2.06 d$ & $0 \mathrm{e}$ & $6.15 \mathrm{c}$ & $35.14 \mathrm{c}$ & $17.29 a$ & $3.12 \mathrm{bc}$ & $0 \mathrm{~g}$ & $39.17 \mathrm{~b}$ \\
\hline & Blotter & 5 & $0.85 \mathrm{e}$ & $0.45 d$ & $3.73 d$ & $23.99 d$ & 15.52ab & $2.57 \mathrm{bc}$ & $1.31 \mathrm{~d}$ & $30.09 c$ \\
\hline \multirow{2}{*}{ Rasht } & PDA & 5 & $7.1 \mathrm{a}$ & $2.47 \mathrm{c}$ & $1.05 f$ & $50.62 a$ & $14.26 \mathrm{bc}$ & $1.05 f$ & $6.15 a$ & $56.67 a$ \\
\hline & Blotter & 5 & $2.72 \mathrm{bc}$ & $0 \mathrm{e}$ & $1.56 \mathrm{e}$ & $41.79 b$ & $17.19 a$ & $1.76 \mathrm{~d}$ & $3.78 \mathrm{~b}$ & $61.80 a$ \\
\hline \multirow{2}{*}{ Talesh } & PDA & 5 & $0 \mathrm{~g}$ & $4.78 a$ & $8.21 a$ & $14.26 \mathrm{e}$ & $11.24 \mathrm{de}$ & $12.3 a$ & $2.11 \mathrm{c}$ & $28.48 \mathrm{bc}$ \\
\hline & Blotter & 5 & $1.15 \mathrm{~d}$ & $0.45 \mathrm{~d}$ & $5.79 b c$ & $11.14 \mathrm{e}$ & $6.25 f$ & $2.16 \mathrm{dc}$ & $0 \mathrm{~g}$ & $20.21 d$ \\
\hline \multirow{2}{*}{ Rostam-Abad } & PDA & 5 & $2.11 \mathrm{c}$ & $0 \mathrm{e}$ & $5.39 b c$ & $18.04 \mathrm{e}$ & $9.12 \mathrm{e}$ & $4.13 \mathrm{~b}$ & $0 \mathrm{~g}$ & $32.46 \mathrm{bc}$ \\
\hline & Blotter & 5 & $2.21 \mathrm{~b}$ & $0 \mathrm{e}$ & $2.92 \mathrm{~d}$ & $4.94 f$ & $2.47 \mathrm{~g}$ & $1.31 \mathrm{ef}$ & $0.45 f$ & $12.35 \mathrm{e}$ \\
\hline
\end{tabular}

*Mean in each column followed by similar letters are not significantly different at $5 \%$ level, according to LSD Test.

Table 3: Mean comparison of seed-born fungi at rice seed samples in different locations of seed production of Guilan province based on PDA and Blotter methods.

\begin{tabular}{|c|c|c|c|c|c|c|c|}
\hline dependent variables & Methode & independent variables & MS & $a \pm E s$ & $b \pm E s$ & $\mathrm{R}^{2}$ & Pr-F \\
\hline \multirow{2}{*}{ A. niger } & PDA & daily precipitation & 4161.44 & $9.69 \pm 7.16$ & $4.26 \pm 9.53$ & 0.87 & 0.035 \\
\hline & Blotter & dailyrelative humidity & 3430.59 & $6.97 \pm 0.92$ & $3.06 \pm 8.65$ & 0.95 & 0.009 \\
\hline \multirow{2}{*}{ A. Flavos } & PDA & - & - & - & - & - & - \\
\hline & Blotter & dailyrelative humidity & 585.53 & $3.94 \pm 3.87$ & $1.73 \pm 3.57$ & 0.91 & 0.051 \\
\hline \multirow{2}{*}{ Alternaria } & PDA & daily sunny hours & 110.06 & $12.09 \pm 35.25$ & $1.57 \pm-4.39$ & 0.95 & 0.010 \\
\hline & Blotter & daily precipitation & 16.92 & $6.53 \pm 14.39$ & $0.85 \pm 1.72$ & 0.85 & 0.054 \\
\hline \multirow{2}{*}{ Blast } & PDA & daily sunny hours & 37.93 & $11.05 \pm 21.55$ & $1.44 \pm-2.58$ & 0.92 & 0.086 \\
\hline & Blotter & - & - & - & - & - & - \\
\hline \multirow{2}{*}{ Penisilum } & PDA & minimum temperature average & 209.68 & $62.92 \pm-149.46$ & $2.9 \pm 7.09$ & 0.90 & 0.022 \\
\hline & Blotter & - & - & - & - & - & - \\
\hline \multirow{2}{*}{ tootal } & PDA & dailyrelative humidity & 2176.18 & $69.44 \pm-95.47$ & $0.95 \pm 1.80$ & 0.93 & 0.072 \\
\hline & Blotter & dailyrelative humidity & 3068.91 & $65.07 \pm 178.14$ & $2.88 \pm 6.22$ & 0.97 & 0.0009 \\
\hline
\end{tabular}

Intercept [a], the values of the slope of the regression line [b], mean squares [MS], coefficient of determination [R2], The level of significance [Pr-F].

Table 4: Analysis of stepwise regression with consideration of seed-born fungi as dependent variables and climatic factor as independent variables.

seeds to this fungi. Regression analysis showed that there is linear relationship and positive significant difference between precipitation and daily humidity rate with severity of fungi A. flavus and A. niger, these functions 87 to 95 percent justified the variation in these characteristics. According to the obtained regression function, it could be stated that for A. niger fungi in PDA method, for every unit increase with increasing daily precipitation and the standard blotter method for per unit increase with increasing daily humidity, the severity of $A$. niger will be increase $9.53 \%$ and $8.65 \%$, respectively. Furthermore, obtained regression function for $A$. flavus fungus by standard blotter method for per unit increase in daily humidity severity of fungi $A$. flavus will increase to 3.57 percent (Table 4 ).

The results for evaluating the effect of climatic factors on the severity of the Alternaria padwickii fungus, showed that in PDA method, there was significant negative linear relationship between the amount of daily sunshine hours and severity of Alternaria fungi and in standard blotter method there was positive and significant linear relationship between precipitation rate and severity of the Alternaria fungus. Obtained functions explain $95 \%$ and $85 \%$ changing percentage in severity of Alternaria padwickii fungus. According to obtained regression function, it could be stated that for Alternaria fungus in PDA method, for every per unit reduction of daily sunshine hours and for standard blotter method for every per unit increase of daily precipitation, severity of this fungus will increase 4.39 percent and 1.72 percent respectively (Table 4).

To examine the characteristics of germination and EC as the dependent variable, climatic factors and fungus factors pathogenic arranged individually then entered into the regression model (Table
5). Among the studied factors A. niger, Alternaria padwickii, daily precipitation and minimum average temperature had the most impact on the characteristic of studied germinating seed samples. These effects could probably be due to the influence of precipitation and daily minimum average temperature on seed aging before harvest [30] or the influence of $A$. niger and $A$. padwickii, on seed deterioration with various changes including the loss of membrane integrity, reduced energy metabolism, impairment of RNA and protein synthesis, and DNA degradation during storage [31]. Makun et al. [32] showed that A. niger and Fusarium fungus were more abundant in rainy weather and dry weather conditions, respectively. Jalander and Gachande [33] by study on the effect of different fungal species of seed-borne fungi of Aspergilluson germination and seedling growth of Bean and Cereals reported that $A$. niger caused reduction in germination percentage, growth of the plumule and radicle. They reported that this effect could be resulted from further metabolic production by $A$. niger fungi than A. flavus and A. nidulans.

The present study investigated the climatic factors during seed development stage [heading to harvest maturity], and daily average precipitation and minimum average temperature were entered in to the regression model. The results showed that daily precipitation with D10 and minimum average temperature with EC had negative linear and significant relationship. Obtained functions were $56 \%$ and $89 \%$, respectively and justified these traits of variation. According to the obtained regression function, it could be stated that for per unit increase in precipitation, D10 will decrease as much as 2.08 hours and per unit increase in minimum average temperature, EC will decrease at a rate of 9.54 micro Siemens per gram. Effect of minimum temperature 


\begin{tabular}{|c|c|c|c|c|c|c|c|}
\hline dependent variables & Methode & Independent variables & MS & $a \pm E s$ & $\mathrm{~b} \pm \mathrm{Es}$ & $\mathrm{R}^{2}$ & Pr-F \\
\hline \multirow{3}{*}{ Percent of germination } & \multirow{2}{*}{ PDA } & A. padwickii & 576.15 & $1.60 \pm 96.11$ & $0.35 \pm-1.14$ & 0.80 & 0.003 \\
\hline & & A. niger & 322.77 & $1.79 \pm 97.01$ & $0.04 \pm-0.09$ & 0.91 & 0.001 \\
\hline & Blotter & A. niger & 619.20 & $1.81 \pm 97.88$ & $0.06 \pm-0.21$ & 0.83 & 0.002 \\
\hline \multirow{2}{*}{ Speed of germination } & PDA & A. niger & 0.000013 & $0.0003 \pm 0.014$ & $0.000007 \pm-0.000024$ & 0.89 & 0.005 \\
\hline & Blotter & A. niger & 0.000017 & $0.0002 \pm 0.014$ & $0.000009 \pm-0.000036$ & 0.88 & 0.0009 \\
\hline \multirow{2}{*}{ Germination uniformity } & PDA & A. niger & 1662.03 & $2.93 \pm 26.72$ & $0.07 \pm 0.26$ & 0.95 & 0.001 \\
\hline & Blotter & A. niger & 2192.56 & $2.56 \pm 26.49$ & $0.08 \pm 0.40$ & 0.96 & 0.0002 \\
\hline \multirow{4}{*}{ D10 } & \multirow{2}{*}{ PDA } & A. niger & 157 & $1.49 \pm 54.6$ & $0.03 \pm 0.08$ & 0.86 & 0.042 \\
\hline & & daily precipitation & 159.72 & $1.78 \pm 57.48$ & $0.90 \pm-2.08$ & 0.56 & 0.010 \\
\hline & \multirow{2}{*}{ Blotter } & A. niger & 171.54 & $1.42 \pm 54.71$ & $0.04 \pm 0.11$ & 0.89 & 0.033 \\
\hline & & daily precipitation & 159.72 & $1.78 \pm 57.48$ & $0.90 \pm-2.08$ & 0.56 & 0.010 \\
\hline \multirow{2}{*}{ D50 } & PDA & A. niger & 525.85 & $1.86 \pm 66.80$ & $0.04 \pm 0.15$ & 0.70 & 0.004 \\
\hline & Blotter & A. niger & 687.17 & $1.66 \pm 66.69$ & $0.05 \pm 0.22$ & 0.84 & 0.0008 \\
\hline \multirow{2}{*}{ D95 } & PDA & A. niger & 2685.75 & $3.57 \pm 87.64$ & $0.09 \pm 0.33$ & 0.87 & 0.001 \\
\hline & Blotter & A. niger & 3321.92 & $3.18 \pm 87.66$ & $0.11 \pm 0.49$ & 0.86 & 0.0002 \\
\hline \multirow{2}{*}{ EC } & PDA & $\begin{array}{l}\text { Minimum temperature } \\
\text { average }\end{array}$ & 379.51 & $66.4 \pm 247.14$ & $3.06 \pm-9.54$ & 0.89 & 0.004 \\
\hline & Blotter & $\begin{array}{c}\text { Minimum temperature } \\
\text { average }\end{array}$ & 379.51 & $66.45 \pm 247.14$ & $3.06 \pm-9.54$ & 0.89 & 0.004 \\
\hline
\end{tabular}

Intercept [a], the values of the slope of the regression line [b], mean squares [MS], coefficient of determination [R2], The level of significance [Pr-F].

Table 5: Analysis of stepwise regression with consideration of characteristics of germination as dependent variables and climatic factor and seed-born fungi as independent variables.

\begin{tabular}{|c|c|c|c|c|c|c|c|c|}
\hline & DF & Gmax & R50 & GU & D10 & D50 & D95 & EC \\
\hline Location & 4 & $238.64^{\star *}$ & $0.000006^{*}$ & $909.88^{* *}$ & $263.92^{\star *}$ & $251.44^{*}$ & $1525.5^{\star *}$ & $549.1^{* *}$ \\
\hline Rep[Location] & 15 & $16.69 n s$ & $0.000002 \mathrm{~ns}$ & $9.78 \mathrm{~ns}$ & $7.44 \mathrm{~ns}$ & $11.55 \mathrm{~ns}$ & $34.69 n s$ & $0.91 \mathrm{~ns}$ \\
\hline Error & 80 & 90.24 & 0.000002 & 199.32 & 37.71 & 83.64 & 293.16 & 36.45 \\
\hline Coefficient Variance & & 10.07 & 10.33 & 12.43 & 10.84 & 12.97 & 17.83 & 14.86 \\
\hline
\end{tabular}

ns: non-significant, * and **: Significant at $5 \%$ and $1 \%$ probability levels, respectively.

Table 6: Analysis of variance for percent of germination [Gmax], germination rate [R50], uniformity of germination [GU], D10, D50 and 95[in order of time that it takes to cumulative germination percentage reach its maximum 10,50and95] and electrical conductivity [micro Siemens. $\mathrm{cm}^{-1} . \mathrm{g}^{-1}$ ] in different locations of seed production of Guilan province.

increase could be caused by reducing activity of $A$. niger. Similar studies have also stated that unfavorable climatic factors during grain filling, to grain chalkiness, specification changes in viscosity, gelatinization temperature and amylose content leads to reduced grain and seed quality [34-37]. Pantuwan [34] reported that although high humidity in the reproductive phase and grain filling phase resulted to increase in grain amylase content, but due to the prolonging period of grain filling period, seed quality reduced by increasing fungi activities. Mobasser et al. [38] by studying wheat seed contamination with seed-borne diseases in cold climatic zone of Iran reported a significant difference between and among provinces and towns with respect to T. leavis infection. Moreover, the data showed clear dispersal of these two species [T. caries and T. leavis]. Khalili aqdam et al. [39] stated that environmental condition caused difference in seed vigor between seed lots of soybean. This difference could due to seedling dry weight, normal seedling percent and more importantly, electrolyte leakage during the electrical conductivity test. Herrera et al. [40] at the study of temperature and precipitation as environmental impact on some wild species of the Grass showed that this factors by changing grain filling period effecting the seed germination and seed vigor.

Among the examined seed-borne fungus, for germination percentage, Alternaria and A. niger were entered into models and for other studied traits only $A$. niger was entered into the regression model. As a negative impact, $A$. niger fungi affects on all rice seed germination characteristic more than all other fungi. In accordance with the results of the present study, Islam et al. [41] stated that there is negative and significant correlation $[R=-97 \%]$ between rate of fungal contaminations and germination percentage in different rice cultivars. Ijaz et al. [42] reported $A$. niger as the most damageable storage fungi among fungal pathogens which were introduced, leads to lower quality and seed germination.

The results of ANOVA (Table 6) showed significant differences among different seed germination characteristics in the different locations of rice seed production in Guilan province. Based on germination percentage, germination rate, germination uniformity and electrical conductivity among the studied locations, Rostam-Abad location had highest seed quality and Rasht and Zeybaknar locations had the lowest quality of seed production (Table 7). According to the findings of this study, it could be stated that climatic conditions such as the lowest precipitation rate, daily humidity average and number of daily sunshine hours in Rostam-Abad reduce the activity and severity of seed-borne fungi, leading to an improvement in seed quality. Several studies have also reported the similar results [43-46]. According to their studies, diversity and difference in severity of pathogenic fungi in the rice seed in various locations were attributed to the climatic conditions and crop management. Also, they stated that during seed development, severity of farm fungi [different species of Aspergillus, Fusarium and Penicilliumin] influenced by certain factors such as high relative humidity and environments temperature as well as high levels of seed moisture during harvest which could increase the contamination to these fungi and reduce seed quality during Storage.

\section{Conclusions}

The results showed that there was large variation in the diversity and 
Citation: Monajjem S, Zainali E, Ghaderi-Far F, Soltani E, Chaleshtari MH, et al. (2014) Evaluation Seed-born Fungi of Rice [Oryza sativa L.] and that Effect on Seed Quality. J Plant Pathol Microb 5: 239. doi:10.4172/2157-7471.1000239

Page 6 of 7

\begin{tabular}{|c|c|c|c|c|c|c|c|}
\hline Seed production Location & Gmax & R50 & GU & D10 & D50 & D95 & EC \\
\hline Amlash & $98 a^{*}$ & $0.0148 a b$ & $29.55 a b$ & $53.92 c$ & $67.43 c$ & $87.84 b$ & $47.38 a$ \\
\hline Zeybakenar & $93.4 b$ & $0.0145 b$ & $41.09 a$ & $53.18 c$ & $70.46 b$ & $103.52 a$ & $38.72 d$ \\
\hline Rasht & $90.6 \mathrm{c}$ & $0.0139 c$ & $38.39 b$ & $57.74 b$ & $73.36 a$ & $100.44 a$ & $43.68 b$ \\
\hline Talesh & $91.6 b c$ & $0.0136 c$ & $33.03 c$ & $62.27 a$ & $74.64 a$ & $102.9 a$ & $39.85 \mathrm{c}$ \\
\hline Rostam-Abad & $97.8 \mathrm{a}$ & $0.015 a$ & $24.29 \mathrm{e}$ & $55.94 b$ & $66.55 c$ & $85.29 b$ & $33.51 \mathrm{e}$ \\
\hline
\end{tabular}

*Mean in each column followed by similar letters are not significantly different at $5 \%$ level, according to LSD Test.

Table 7: Mean comparison for percent of germination [Gmax], germination rate [R50], uniformity of germination [GU], D10, D50 and 95 [in order of time that it takes to cumulative germination percentage reach its maximum 10, 50 and 95] and electrical conductivity [micro Siemens. $\mathrm{cm}^{-1}$. $\mathrm{g}^{-1}$ ] in different locations of seed production of Guilan province.

severity of fungal contamination to seed-borne fungi in seed samples. Among seed-borne fungi, Aspergillus niger and Aspergillus flavus had the most severity rate compared to others. Among the climatic factors, daily humidity, daily sunshine hours, daily precipitation and daily minimum average temperature were the most important factors that effected the distribution of studied seed-borne fungi types except Fusarium moniliforme and Bipolaris oryzae. Evaluation of germination characteristics of rice seeds under the influence of climatic factors on seed development stage and seed-borne fungi showed that there was a significant negative linear relationship between the average of daily precipitation amount with D10 and the average of minimum temperature with EC. Also among studied seed-borne fungi, for germination percentage, Alternaria and A. niger fungus and for other germination traits only $A$. niger were significant. From negative impact A. niger fungi compared with others fungus implied all characteristics on rice seed germination. Among the five different locations, samples from Rasht and zeybaknar had the highest contamination to seedborne fungi pathogens, also the most severity of A. flavus and A. niger fungi were observed in these locations. Samples from Rostam-Abad had the least seed-borne fungi; this could be due to low precipitation rate and daily mean average humidity per day and number of sunshine hours in the studied location.

\section{Acknowledgements}

The authors are thankful to the Department of Agronomy, Gorgan University of Agricultural Sciences and Natural Resources for financial support of this research and the Rice Research Institute of Iran, Rasht for permission to use laboratory facilities.

\section{References}

1. Biemond PC, Stomph TJ, Kamara A, Abdoulaye T, Hearne S, et al. (2012) Are investments in an informal seed system for cowpea a worthwhile endeavour? Int J Plant Prod 6: 367-386.

2. Fujisaka S, Guino RA, Lubigan RT, Moody K (1993) Farmers' Rice Seed Management Practices and Resulting Weed Seed Contamination in the Philippines. Seed Scienceand Technology 21: 149-157.

3. Bishaw Z (2004) Wheat and barley seed systems in Ethiopia and Syria. Ph.D. Thesis. Wageningen University.

4. Raj Paroda S, Dasgupta Bhag Mal SS, Singh ML, Gyanendra S (2013) Proceedings of the Regional Consultation on Improving Wheat Productivity in Asia, Bangkok, Thailand; 26-27 April, 2012. p. 224.

5. FAO (2012) The FAO Statistical Yearbook, Food and Agricultural Oraganization of the United Nations, Rome, Italy.

6. Jihad-Agricultural organization in Guilan province (2012) Cereal in statistics. Statistics and Information Department, Ministry of Agriculture.

7. Mew TW, Gonzales P (2002) A handbook of rice seedborne fungi. Los Bafios (Philippines): ISTA: Science Publishers. p. 83.

8. Nghiep HV, Gaur A (2005) Efficacy of seed treatment in improving seed quality in rice (Oryza sativa I.). Omonrice 13: 42-51.

9. Ahmed M, Hossain M, Hassan K, Kanta Dash Ch (2013) Seed Health and Quality Test of Three Rice Varieties for the Detection of Fungi Associated with Seed Sample. Universal Journal of Plant Science 1: 37-42.
10. Fakir GA (1983) Teaching, Research and Training Activities on Seed Pathology in Bangladesh. Seed Science and Technology. 11: 1345-1352.

11. Javaid MS, Wahid A, Idrees M, Gill MA, Saleem A (2002) Seed mycoflora studies in rice. Pakistan J. Phytopathol 14: 132-134.

12. Nguefack J, Nguikwie SK, Fotio D (2007) Fungicidal potential of essential oils and fractions from Cymbopogoncitratus, Ocimumgratissimmum and Thymus vulgaris to control Alternariapadwickii and Bipolarisoryzae, two seed-borne fungi of rice (Oryza sativa L.). Journal of Essential Oil Research. 17: 581-587.

13. Gopalakrishnan C, Kamalakannan A, Valluvaparidasan V (2010) Survey of Seed-Borne Fungi Associated with Rice Seeds in Tamil Nadu, India. libyan agriculture research center journal international. 1: 307-309.

14. Uma V, Wesely EG (2013) Seed-borne fungi of rice from South Tamil Nadu. Journal of Academia and Industrial Research, 1: 612-614.

15. Van Du P, Cam Loan L, DucCuong N, Van Nghiep H, Danh Thach N (2001) Survey on seed-borne fungi and its effects on grain quality of common rice cultivars in the Mekong Delta. Omonrice 9: 107-113.

16. Karami S, Soroush S, Zarea L, HashemiFesharaki SH (2012) Effect of seed born fungi, Fusariumspp and Bipolarisoryzae on rice seed germination. National Conference on Advances in Agronomy, Islamic Azad University, Shahr-e-Qods Branch.

17. Meteorological Office of Guilan Province (2014) Climate characteristics of Gilan.

18. Sauer DB, Burroughs R (1986) Disinfection of seed surfaces with Sodium Hypochlorite. Phytophatology. 76: 745-749.

19. ISTA (2009) International Rules for Seed Testing. Annex to Chapter 7 Seed HealthTesting. Seed Health Testing Methods. International Seed Testing Association, Bassersdorf, Switzerland.

20. Soltani A, Gholipoor M, Zeinali E (2006) Seed reserve utilization and seedling growth of wheat as affected by drought and salinity. Environmental and Experimental Botany. 55: 195-200.

21. Soltani A, Maddah V (2010) Simple, applied programs for education and research in agronomy. Shahid Beheshti University Press.

22. Farooq M, Basra SMA, Hafeez K (2005) Seed invigoration by osmo hardening in indica and japonica rice. Seed Scienceand Technology. 33: 623-628.

23. Mathur SB, Kongdal E (2003) Common laboratory seed health testing method for detection fungi. First edition. The International Seed Testing Assosiation (ISTA).

24. Agrawal RL (1995) Seed technology. 2nd Edition. Oxford and Ibh Publishinh Co. Pvt. Ltd, New Dehli.

25. Soltani A (2007) Application of SAS in statistical analysis, Jahad-e-Daneshga of Mashhad Press, 182: 26

26. Trung T, Bailly JD, Querin A, Le bras P, Guerre P (2001) Fungal contamination of rice from South Vietnam, mycotoxinogenesis of selected strains and residues in rice. Journal of Veterinary Medicine: Research. 152: 555-560.

27. Reddy CS, Reddy KRN, Kumar RN, Laha GS, Muralidharan K (2004) Exploration of aflatoxin contamination and its management in rice journal of mycology and plant pathology. 34: 816-820.

28. Mosa-Nejad S, Alizadeh A, Safai N (2010) The effect of climatic factors on the sporulation of rice blast pathogen in Guilan province. Journal of Science and Technology of Agriculture and Natural Resources 13: 315-326.

29. Aghili SR, Shokohi T, Khosravi, AR, Salmanian B (2012) Mycoflora 
Citation: Monajjem S, Zainali E, Ghaderi-Far F, Soltani E, Chaleshtari MH, et al. (2014) Evaluation Seed-born Fungi of Rice [Oryza sativa L.] and that Effect on Seed Quality. J Plant Pathol Microb 5: 239. doi:10.4172/2157-7471.1000239

Contamination of Consumed Rice in Mazandaran. Journal of Mazandaran University of Medical Sciences. 22: 279-285.

30. McDonald MB (1999) Seed deterioration: physiology, repair and assessment. Seed Science Technology 27: 177-237.

31. Kibinza S, Vinel D, Côme D, Bailly C, Corbineau F (2006) Sunflower seed deterioration as related to moisture content during ageing, energy metabolism and active oxygen species scavenging. Physiologia Plantarum 128: 496-506.

32. Makun HA, Gbodi TA, Tijani AS, Abai A, Kadiri GU (2007) Toxicologic screening of fungi isolated from millet (pennisetumspp) during the rainy and dry harmattan seasons in Niger state, Nigeria. African Journal of Biotechnology. 6: 034-040.

33. Jalander V, Gachande BD (2012) Effect of fungal metabolites of some rhizosphere soil fungal on seed germination and seedling growth of some pulses and cereals. Science Research Reporter. 2: 265-267.

34. Pantuwan G (2001) Yield responses in rice (Oryza sativa L.) genotypes to wate deficit in rain fed lowlands. Ph.D. Thesis. University of Queensland, Australia.

35. Carlos ACC, Orivaldo A, Rogério PS, Gustavo PM (2008) Grain quality of upland rice cultivars in response to cropping systems in the Brazilian tropical savanna. scientiaagricola (Piracicaba, Braz.). 65: 468-473.

36. Thitisaksakul M, Jiménez RC, Arias MC, Beckles DM (2012) Effects of environmental factors on cereal starch biosynthesis and composition. Journal of Cereal Science 56: 67-80.

37. Siebenmorgen TJ, Grigg BC, Lanning SB (2013) Impacts of pre-harvest factors during kernel development on rice quality and functionality. annual review food science technology. 4: 101-15.

38. Mobasser S, Jazayeri MR, Khazaei F, Sadeghi L (2012) Wheat seed contamination with seed-borne diseases in cold climatic zone of Iran International Journal of Plant Production 6: 337-352.

39. Khaliliaqdam N, Soltani A, Latifi N, Ghaderi-Far F (2012) Effect of environmenta conditions on soybean seed vigor in different area of Iran. Electronic journal of crop production. 5: 87-104

40. Herrera F, Ocumpaugh WR, Ortega-S JA, Lioyd-Reilley J, Rasmuseen GA, et al. (2008). Environmental influences on seed quality of windmill grass ecotypes in south Texas. Agronomy J 100: 1205-1210.

41. Islam MS, Rahman H, Pervez Z, Mahmud MR, Alam A (2012) Studies on Seedborne Fungi in Rice Cultivars Grown in non saline Tidal zone of Patuakhali and their effect on seed germination. Bangladesh Research Publication. 6: 286290.

42. ljaz A, Anwar SA, Riaz A, Khan MSA (2001) Seed-borne pathogens associated with wheat and their role in poor germination. Pakistan Journal of Phytopathology 13: 102-106.

43. Ismail, MA, Abdel-Hafez SII, Moharam AM (2002) Aeromycobiota of western desert of Egypt. African Journal of Science and Technology 3: 1-9.

44. Bankole SA, Adebanjo A (2003) Mycotoxins in food in West Africa:curren situation and possibilities of controlling it. African Journal of Biotechnology 2: $254-263$.

45. Habib A, Javed N, Sahi, ST, Waheed M (2012) Detection of seed-borne mycoflora of different coarse and fine rice varieties and their management through seed treatment. Pakistan Journal of Phytopathology. 24: 133-136.

46. Archana B, Prakash HS (2013) Survey of seed-borne fungi association with rice seeds in India. International journal of research in pure and applied microbiology. 3: 25-29. 